\title{
A PRESENT PAST: REPRESENTATIONS OF POLISH-JEWISH COEXISTENCE IN WORD AND IMAGE
}

Katarzyna Liszka

Marcos Silber

\section{A Present Past: Representations of Polish-Jewish Coexistence in Word and Image}

\section{PREFACE}

Scholars have produced important studies emphasizing mutual JewishPolish coexistence, interaction, and "influence." Despite the growing interest in multi-ethnic and multi-religious everyday coexistence, the subject of its representation has so far received only selective scholarly attention. A handful of comprehensive medium-oriented studies comparing perceptions of Polish-Jewish neighborliness have been produced, dealing primarily with coexistence on a daily basis. By applying a comparative approach and discussing how Polish-Jewish everyday coexistence has been represented in literature and art, this section is an attempt to encourage scholars to deal with this lacuna and create a more thorough picture of the modern cultural memory of "living together."

This collection of articles is partly the result of a workshop held in POLIN Museum in October 2016 that explored how the "past" is "present" in "the present." The past is being perpetually recreated and used as a tool to construct contemporary times by those presenting and representing it. The expression "a present past" was coined in 1993 by Richard Terdiman to emphasize the persistence of the past in the present. ${ }^{1}$ We complete Terdiman's motto by adding John Bodnar's statement that public memory is not only an inaccurate representation of the past, but is in fact constructed according to the needs of both the present and the dreamed future, as imagined by certain social groups that have obtained the power to represent

\footnotetext{
${ }^{1}$ Richard Terdiman, Present Past: Modernity and the Memory Crisis (New York, 1993).
} 
and interpret these memories, making memory itself a contested social construction. ${ }^{2}$ John Bodnar distinguishes "public memory" from "vernacular memory." The former expresses the construction of the past event by the hegemonic members of a community, whereas the latter represents the construction of the same event in a more private, personalized recollection. The same event will be remembered differently by various individuals, and moreover there is always a large number of vernacular memories, many of them in conflict with one another. Leading groups and individuals, on the other hand, would try to construct a more uniform or coherent picture of the past, and sometimes to instrumentalize it. Public memory, in this sense, includes and reformulates multiple "vernacular memories." In this regard, according to Bodnar, public memory imposes a structure of meaning upon a broad range of "vernacular," personal, memories. ${ }^{3}$

The articles presented in this issue of Studia Judaica examine how writers and artists remembered and represented Polish-Jewish coexistence, and how they transmitted the multiple layers of "living together" to their audiences.

While there has been an extended debate on the nature of "representations" in general, and on "social representations" in particular, we would like to clarify our use of the term. ${ }^{4}$ At the crossroads between the individual and society, representations are an in-between space linking objects, subjects, and activities. Representations are embodied in communication and in imaginations, collective and individual, and are shared in a way similar to language. In this sense "shared" refers to Rom Harré's definition of a collective plurality where all those in the group have overlapping parts of the whole, but the whole is only comprehended by reference to the collective. ${ }^{5}$

2 John Bodnar, Remaking America: Public Memory, Commemoration, and Patriotism in the Twentieth Century (Princeton, 1992), 182.

${ }^{3}$ Ibid., 13-14.

${ }^{4}$ Serge Moscovici, "The Phenomenon of Social Representations," in Robert Farr, Serge Moscovici (eds.), Social Representations (Cambridge, 1984), 3-70; Robert Farr, "Social Representations: A French Tradition of Research," Journal for the Theory of Social Behaviour 17 (1987), 343-365; Agnes Allansdottir, Sandra Jovchelovitch, Angela Stathopoulou, "Social Representations: The Versatility of a Concept," Papers on Social Representations 2 (1993), 3-10; Wolfgang Wagner, "Description, Explanation and Method in Social Representation Research," Papers on Social Representations 4 (1995), 1-21; Gordon Sammut, Eleni Andreouli, George Gaskell, Jaan Valsiner (eds.), The Cambridge Handbook of Social Representations (Cambridge, 2015).

${ }^{5}$ Rom Harré, "Some Reflections on the Concept of 'Social Representation'," Social Research 51 (1984), 927-938. 
The process of representing is simultaneously individual and collective; an activity in which a subject creates an observable outcome in a system of mutual constitution. In the case of Aviv Livnat's article, the representations of Polish-Jewish coexistence are reflected in metaloplastic works created by artists; in the case of Dorota Burda-Fischer and Alina Molisak, in the literary works created by writers and poets in Polish, Hebrew, and Yiddish dealing directly with the coexistence of Poles and Jews; in the case of Tomasz Żukowski, in the iconic film Border Street directed by Aleksander Ford, portraying Polish-Jewish relations during the Holocaust. Eugenia Prokop-Janiec's study addresses the popular press in Polish created by publicists, journalists, and editors for the growing Jewish population that used the Polish language in its daily life. We may observe multiple forms of an original idea in different pragmatic contexts.

In his article, Aviv Livnat examines the "voice" behind the traditional technique of metaloplastics, thereby underscoring that the word empowers the image. According to Livnat, metaloplastic works are "a subtle 'voice' ... hidden behind the façade of tradition with which the art of copper hammering was usually associated." Livnat interprets the representations on metaloplastic works from the late 1930 s as a way to create a story of collaboration between people of different nations against the background of fears about war and death. From the perspective of Bodnar's instrumental presentism, the metaloplastic artists focused upon the needs of the present and their dreams for the future.

However, representation is not an unequivocal and indisputable concept. In Difference and Repetition, Gilles Deleuze critiques representation as a dominant image of thought. ${ }^{7}$ For Deleuze, representational thought is "sedentary," categorical, and judgemental: it is the enemy of difference, movement, change, and the emergence of the new. As he writes, pure difference, "difference in itself," is "crucified" by representation, tied and fixed by its "quadripartite fetters, under which only that which is identical, similar, analogous, or opposed can be considered difference." 8 Representation serves as the "dogmatic image of thought" because it categorizes and judges the world through pre-conceived rational common sense, according to principles of truth and error in an established order.

${ }^{6}$ Aviv Livnat, "Copper and Its Meanderings: Perspectives on Jewish Metaloplastics in a Polish Context," this issue, p. 50.

7 Gilles Deleuze, Différence et répétition (Paris, 1968); id., Difference and Repetition, trans. Paul Patton (London, 1994).

${ }^{8}$ Ibid., 174. 
In place of the hierarchy implied in the process of creating, recreating, reproducing, and analyzing representations, different theorists have found different words for a non-hierarchical organization. Deleuze suggests the concept of assemblage, ${ }^{9}$ which Lecercle characterizes as "the Deleuzean logic of unholy mixtures, an AND rather than an INSTEAD OF logic."10

According to the concept of assemblage, the "world" is not separate from the linguistic or category systems that "represent" it. As Deleuze writes, "In assemblages, you find states of things, bodies, various combinations of bodies, hodgepodges; but you also find utterances, modes of expression, and whole regimes of signs." ${ }^{11}$ Words collide and connect with things on the same ontological level, and therefore language is not an external objective element that would allow it to represent "the world." The world offers events to tell. The narrative process of telling transforms the events. Narrative imitates life, and life imitates narrative in a continuous spiral dynamics.

Eugenia Prokop-Janiec is highly sensitive to the process in which language is not a neutral category to "describe" or "analyze" the "representation." In "Polish Language in Jewish Daily Life: The Press and Popular Literature in the 1930s," the author is not interested in indicators of Polonization that confirm the presence and expansion of the Polish language in Jewish life, but rather in how the vernacularization of Polish is represented or expressed in the mass and popular press of interwar Poland. According to Prokop-Janiec, the interwar vernacularization of the Polish language manifests itself in its growing instrumental value and change in its symbolic signification. On the other hand, the author is of the opinion that the increasingly widespread use of Polish was accompanied by the weakening of its role as a symbol of integration with Polishness and Polish culture - a role it was assigned by nineteenth-century integrationist programs.

${ }^{9}$ Gilles Deleuze, Félix Guattari, Mille plateaux (Paris, 1980); eid., A Thousand Plateaus, trans. Brian Massumi (London-New York, 2004).

${ }^{10}$ Jean-Jacques Lecercle, Deleuze and Language (New York, 2002), 53-54. Others suggest other concepts: entanglement [Karen Barad, Meeting the Universe Halfway (Durham-London, 2007)]; mangle [Andrew Pickering, "The Mangle of Practice: Agency and Emergence in the Sociology of Science," American Journal of Sociology 99 (1993), 559-589, and Susan Hekman, The Material of Knowledge: Feminist Disclosures (Bloomington, 2010)]; manifold [Manuel DeLanda, Intensive Science and Virtual Philosophy (London, 2002)]; actor network [Bruno Latour, Reassembling the Social: An Introduction to Actor-NetworkTheory (Oxford, 2007)].

${ }_{11}$ Deleuze, Difference and Repetition, 177. 